\title{
REPRESENTASI KALIMAT PADA TUTURAN ANAK USIA 3,6 TAHUN
}

\author{
Nursalam $^{1}$ dan Nurhikmah ${ }^{2}$ \\ ${ }^{1}$ Universitas Negeri Malang \\ Jalan Semarang No.5, Kota Malang, Jawa Timur, 65145 \\ ${ }^{2}$ Universitas Islam Negeri Alauddin Makassar \\ Jalan Sultan Alauddin No.63, Romangpolong, Somba Opu, Sulawesi Selatan, 92113 \\ Surel: nursalam291290@gmail.com com
}

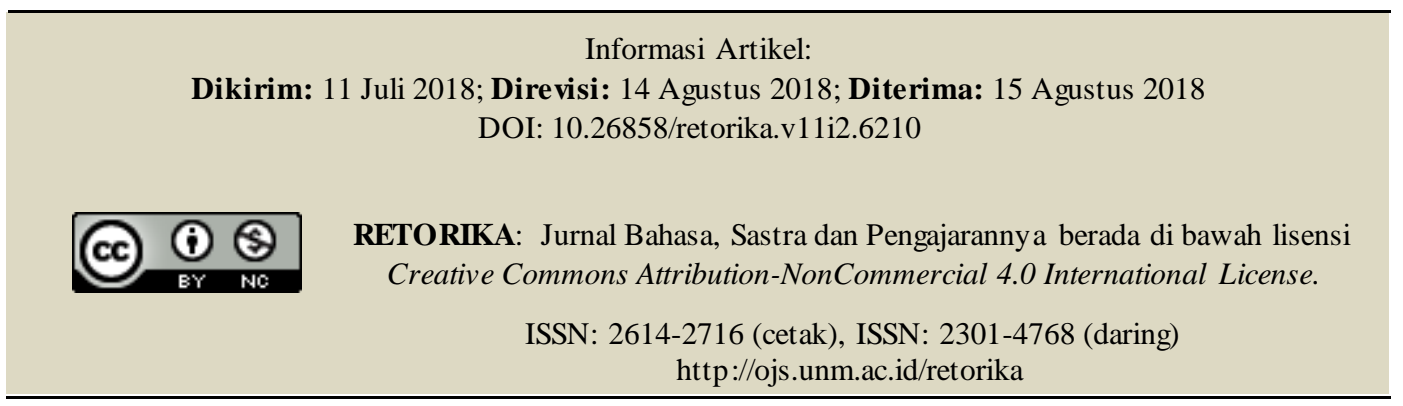

Abtract: Sentence Representation in Children's Speech 3.6 Years. This research is to describe the utterances of people's sentences for 3.6 years. This research is a type of qualitative research. The data in this study are children's verbal speech recorded through the recording process. The data comes from the utterance of a 3.6 year old child. The data analysis stage was carried out in three stages, namely (1) reduction, (2) presentation, and (3) conclusion. Based on the data found four types of sentences spoken by children 3.6 years, namely the imperative, question (interrogative), exclamation (interjection), and news (declarative). Based on the type of speech children of 3.6 years have been able to speak the sentence permanently but cannot use the right words because nothing is complete.

\begin{abstract}
Abstrak: Representasi Kalimat pada Tuturan Anak 3,6 Tahun. Penelitian ini bertujuan mendeskripsikan tuturan kalimat anak usia 3,6 tahun. Data dalam penelitian ini adalah tuturan verbal anak yang diperoleh melalui proses perekaman. Data bersumber dari tuturan seorang anak bersuia 3,6 tahun. Tahap analisis data yang dilakukan ada tiga tahap, yakni tahap (1) reduksi, (2) penyajian, dan (3) penarikan kesimpulan. Berdasarkan data ditemukan empat jenis kalimat yang dituturkan anak usia 3,6 tahun, yakni kalimat perintah (imperatif), pertanyaan (interogatif), seru (interjeksi), dan berita (deklaratif). Berdasarkan keempat jenis kalimat tersebut anak usia 3,6 tahun sudah mampu menuturkan kalimat secara gramatikal namun belum mampu menggunakan tuturan kalimat secara sempurna karena unsur sintaksisnya belum lengkap.
\end{abstract}

Kata kunci: pemerolehan bahasa, representasi kalimat, sintaksis, tuturan anak 
Penggunaan tuturan kalimat pada anak umumnya berbeda dengan tuturan orang dewasa. Kompetensi bahasa anak masih terbatas sehingga dalam tuturan anak masih terjadi kesalahan dan kekeliruan dalam penggunaan struktur bahasanya. Selain itu, orang dewasa sudah dilengkapi dengan alat gramtikal yang baik sehingga mampu berkomunikasi secara sempurna.

Tahap perkembangan bahasa anak melalui tingkatan tertentu. Hal tersebut sesuai dengan pendapat Tarigan (2011:5) yang mengatakan bahwa pemerolehan bahasa anak memiliki suatu rangkaian kesatuan yang bergerak dari ucapan satu kata sederhana menuju gabungan kata yang lebih rumit. Hal ini sejalan dengan pendapat Richard (2002:284) yang mengatakan bahwa pemerolehan bahasa anak adalah bagian dari proses mental secara bertahap dengan penguasaan kosa kata yang mudah hingga ke tingkatan kosa kata tinggi sebagai proses perkembangan kompetensi berbahasa anak. Oleh karena itu, proses perkembangan bahasa anak dapat dilihat dari kelengkapan unsur sintaksis kalimat yang diucapkannya.

Perkembangan bahasa anak pada dasarnya dapat dilihat melalui penguasaan kosa katanya yang dimulai dari satu kata (atau bagian kata). Bagi anak, kata ini sebenarnya adalah kalimat penuh, tetapi belum dapat mengatakan lebih dari satu kata, anak hanya mengambil satu kata dari seluruh kalimat itu (Dardjowidjojo, 2014:246). Namun demikian, seiring dengan perkembangan usia kognitifnya, anak mulai mencoba menuturkan kata demi kata dalam bentuk kalimat. Hal ini sejalan dengan konsep teori kognitif Piaget bahwa kemampuan berbahasa anak berbanding dengan perkembangan kognisinya yang ditentukan oleh LAD (language aquitition device) dan pengaruh gen yang diturunkan secara individual.

Secara umum perkembangan bahasa anak melalui tahapan khusus. Menurut Aitchison (dalam Trinowiswanto, 2016:3) perkembangan bahasa anak terdiri atas sepuluh tahap. Usia 3 bulan mulai dapat meraban, usia 9 bulan mulai terdengar intonasinya, usia 1 tahun membuat kalimat 1 satu kata, usia 2 tahun mampu membuat kalimat empat kata, dapat membuat kalimat negatif, menguasai infleksi, pelafalan vocal telah sempurna, usia 3,6 tahun pelafalan konsonan telah sempurna, usia 4,0 penguasaan kalimat secara tepat, tetapi masih terbatas, usia 5 tahun konstruksi morfologis telah sempurna, dan usia 10 tahun anak sudah matang berbicara.
Berdasarkan tahapan perkembangan bahasa anak tersebut, anak usia 3,6 tahun merupakan periode estetis prasekolah. Anak usia 3,6 tahun telah memperoleh banyak kosakata sehingga mampu menuturkan beberapa kalimat. Hal ini sejalan dengan temuan Mushaitir (2016:34) yang mengatakan bahwa anak-anak sudah memperoleh jenis-jenis kalimat tak lengkap, inversi, tunggal, majemuk, berita, perintah, dan tanya sejak duduk dibangku TK. Namun demikian, anak di usia tersebut cenderung menggunakan bahasa ibunya. Selain itu, struktur tuturan kalimat anak belum sempurna karena kemampuan tata bahasanya yang masih terbatas. Oleh karena itu, kajian ini dianggap penting dilakukan untuk mengetahui tingkat perkembangan kompetensi sintaksis anak melalui empat jenis tuturan kalimat yakni kalimat imperatif, interogatif, interjeksi, dan deklaratif (Alwi, dkk., 2003:336).

Penelitian terhadap perkembangan sintaksis anak sudah pernah dilakukan peneliti sebelumnya. Hutauruk (2015) meneliti masalah anakanak dalam akuisisi bahasa pertama di usia 1-3 tahun di Ressort Balata. Hasil penelitian ini menunjukkan bahwa ada 9 masalah dalam akuisisi bahasa pertama, yaitu kesalahan tata bahasa, kesalahan fonologi, kesalahan pengucapan, imitasi, pengulangan, koreksi, menunjukkan pertanyaan, belajar dengan pengalaman, dan kemalasan. Mushaitir (2016) mengkaji pemerolehan sintaksis (B1) bahasa Sasak pada anak usia 4-6 tahun. Penelitian ini mendeskripsikan pemerolehan sintaksis (B1) bahasa sasak pada anak usia 4-6 tahun di Lombok Timur melalui permainan tradisional. Hasil penelitian ini menunjukkan bahwa anak usia 4-6 tahun mampu menggunakan kalimat tunggal dengan dengan klausa lengkap dan tidak lengkap serta secara internal memiliki struktur runtut dan struktur inversi. Selain itu, anak diusia tersebut mampu menggunakan kalimat majemuk koordinatif dan kalimat majemuk subordinatif. Saputri (2018) melakukan penelitian tentang pemerolehan bahasa anak usia 3 tahun. Hasil penelitian Saputri menujukkan bahwa anak usia 3 tahun mampu menggunakan afiksasi yakni prefiks $\{$ di- $\}$, sufiks $\{-a n\}$, sufiks $\{-k a n\}$ yang sering muncul sebagai $\{$-in\}, konfiks \{di-kan\} yang muncul sebagai $\{$ di-in $\}$. Kemudian pemerolehan sintaksis anak diusia tersebut mampu menggunakan kalimat deklaratif dan kalimat imperatif.

Penelitian-penelitian yang telah diungkap menjadi landasan dalam mengkaji representasi sintaksis anak usia 3,6 tahun. Dari aspek kajian, 
penelitian ini berbeda dengan penelitian terdahulu. Penelitian ini secara khusus membahas tentang aspek tuturan sintaksis anak usia 3,6 tahun yang meliputi tuturan kalimat interogatif, kalimat deklaratif, kalimat interjeksi, dan kalimat imperatif. Berbeda dengan tujuan ketiga penelitian sebelumnya yang membahas tentang masalah pemerolehan bahasa anak yang meliputi proses morfologi dan sintaksis anak dengan kalimat deklaratif dan imperatifnya. Subjek penelitian ini berbeda latar belakang sosial dengan subjek penelitian sebelumnya.

Pemilihan subjek penelitian anak usia 3,6 tahun didasarkan pada rasionalisasi bahwa anak di usia 3,6 tahun sudah memiliki kosa kata dalam pemerolehan bahasanya sehingga sudah mampu menuturkan kalimat dengan jumlah kata 2 sampai 4 kata. Penelitian difokuskan untuk mengungkap representasi kalimat anak, meliputi kalimat deklaratif, kalimat imperatif, kalimat interogatif, dan kalimat interjeksi. Hasil penelitian diharapkan berkontribusi terhadap teori pemerolehan bahasa anak. Secara praktis, penelitian diharapkan menjadi landasan pembelajaran bahasa Indonesia di kelas awal sekolah dasar.

\section{METODE}

Penelitian ini termasuk jenis penelitian kualitatif yang bertujuan untuk menemukan pola hubungan yang bersifat interaktif, menemukan teori, menggambarkan realitas yang kompleks, dan memperoleh pemahaman makna (Sugiyono, 2013:23). Sumber dan data dalam penelitian ini adalah transkripsi rekaman tuturan verbal anak usia 3,6 tahun yang bernama Nadia. Subjek penelitian ini adalah anak pertama dan masih duduk di bangku TK. Subjek penelitian memiliki bahasa pertama (B1) bahasa Makassar dan memiliki perilaku aktif dalam berkomunikasi. Kedua orang tua subjek penelitian ini memiliki pekerjaan sebagai pedagang dan ibu rumah tangga.

Data tuturan verbal diperoleh ketika Nadia sedang bermain dengan ibunya pada tahun 2017 selama dua minggu untuk menggetahui tingkat kompetensi tuturan kalimatnya. Transkripsi tuturan disajikan dan dianalisis berdasarkan tataran sintaksis yang mengacu pada bentuk kalimat interogatif, deklaratif, imperatif, dan interjeksi. Teknik pengumpulan data yang digunakan adalah melalui perekaman. Perekaman dilakukan secara dominan dalam aktivitas Nadia sebagai subjek dengan menggunakan satu unit smartphone.
Tahap analisis data di dalam penelitian ini melalui tiga tahap, yakni tahap (1) reduksi, (2) penyajian, dan (3) penarikan kesimpulan (Miles dan Huberman (2014:16-18). Pertama, tahap reduksi dilakukan dengan empat cara, yaitu (1) melakukan proses transkripsi data tuturan ke dalam bentuk teks tulisan (2) data yang telah ditranskripsi kemudian diidentifikasi sesuai dengan tujuan penelitian, (3) melakukan proses pengklasifikasian berdasarkan tujuan penelitian yakni, representasi kalimat interogatif, kalimat deklaratif, kalimat imperatif, dan kalimat interjeksi, dan (4) melakukan pemaknaan terhadap data yang sebelumnya telah diklasifikasi. Kedua, tahap penyajian, yakni menyajikan data yang telah diklasifikasikan ke dalam bentuk tabel. Ketiga, tahap penarikan kesimpulan sebagai tahap akhir dengan cara melakukan proses verifikasi ulang terhadap data awal.

\section{HASIL DAN PEMBAHASAN}

\section{Hasil}

Bentuk tuturan kalimat anak usia 3,6 tahun yang ditemukan dalam kajian ini diuraikan sebagai berikut.

\section{Repesentasi Kalimat Deklaratif}

Kalimat deklaratif yang dituturkan Nadia yang masih berusia 3,6 tahun secara umum sudah memiliki makna gramatikal. Namun demikian, masih banyak menggunakan diksi yang tidak baku. Hal ini dibuktikan melalui data (1) berikut ini.

\author{
Data (1) \\ Ibu: Mana bonekata nak? \\ Nadia: Nenettu, Mama. \\ Ibu: Nanti saya carikanki nak. \\ Ibu: Sinimaki main pale nak. \\ Nadia: Tidak ada mainantu Mama. \\ Nadia: Itu bonetatu mama. \\ Ibu: Saya ambilkan nak? \\ Ibu:Sini bonekanya nak! \\ Ibu: Mama sisir rambut bonekanya dulu \\ Nadia: Atu kasih bajutu mama.
}

Berdasarkan tuturan pada data (1), kalimat deklaratif ditandai pada kalimat (1) Nenettu Mama, (2) Itu bonetatu Mama, (3) Atu kasih bajutu Mama. Bentuk tuturan kalimat deklaratif yang pertama Menettu Mama adalah kalimat yang ber- 
isi informasi bahwa yang mengambil boneka tersebut adalah nenek Nadia. Secara sintaksis kalimat tersebut belum lengkap karena tidak memiliki unsur predikat. Fungsi sintaksis kalimat tersebut hanya terdiri atas subjek dan objek sehingga dinilai bukan sebagai kalimat yang efektif. Kalimat deklaratif yang dituturkan Nadia cenderung mengulang kalimat yang sering didengar oleh orang-orang di sekitarnya. Selain itu, anak di usia tersebut akan mampu merekam segala informasi yang dilihat dan didengarnya. Hal inilah yang dituturkan Nadia ketika mendapat stimulus pertanyaan dari ibunya tentang mainannya dan dijawab sesuai dengan apa yang diingatnya.

Tuturan kalimat deklaratif yang dituturkan Nadia sebelumnya secara gramatikal sudah memiliki makna, namun terdapat kesalahan dalam proses pemilihan diksinya. Kesalahan tersebut terletak dalam penyebutan kata nenettu. Kata nenettu cenderung dipengaruhi oleh bahasa ibu Nadia yang ditandai dengan sufiks - $t u$. Padahal dalam bahasa Indonesia yang benar adalah sufiks - $k u$ sehingga menjadi kata nenek $k u$.

Kalimat deklaratif yang kedua adalah Itu bonetatu mama. Secara sintaksis kalimat tersebut tidak memiliki unsur predikat hanya subjek dan objek. Kesalahan dalam tuturan kalimat deklaratif tersebut juga terletak pada penggunaan kata bonetatu. Nadia belum mampu membedakan huruf konsonan velar $(\mathrm{k})$ dan alveolar $(\mathrm{t})$ sehingga kata bonekaku diucapkan bonetatu. Meskipun belum mampu menuturkan kalimat secara sempurna, Nadia yang berusia 3,6 tahun sudah mampu mengucapkan tiga kata bahkan lebih dalam tuturan kalimat yang diujarkannya.

Pola sintaksis tuturan anak di usia 3,6 tahun secara umum belum sempurna. Hal ini dapat dilihat dari fungsi sintaksis kalimat deklaratif tersebut. Namun demikian, tuturan kalimat anak di usia 3,6 tahun sudah mampu menyesuaikan dengan keadaan dan lingkungannya. Hal ini juga dipertegas oleh Darjowidjojo (2016:258) bahwa macam kata yang dikuasai anak mengikuti prinsip sini dan kini. Oleh karena itu, kata-kata yang akan diperoleh anak pada awal ujarannya ditentukan oleh lingkungannya sehingga anak yang diarahkan dan dilatih berbahasa dengan sebaik-baiknya setiap saat, pemerolehan bahasanya akan menjadi baik (Aziz, 2012:84).

Kalimat deklaratif ketiga Atu kasih bajutu mama adalah sebuah kalimat deklaratif yang berisi pernyataan. Namun demikian, kalimat deklaratif yang dituturkan oleh Nadia tidak sesuai de- ngan maksud kalimat perintah yang dituturkan ibnya karena Nadia menjawab dengan berbeda. Hal tersebut disebabkan Nadia tidak memiliki pemahaman yang sama dengan ibunya. Nadia juga belum memahami dalam menempatkan kata pronomina dalam kalimat yang dituturkannya sehingga kalimat yang dituturkannya tidak efektif. Oleh karena itu, kalimat deklaratif yang dituturkan Nadia dapat dikategorikan kalimat deklaratif yang berbentuk inversi, runtut, bentuk aktif, bentuk pasif (Alwi, 2003:353). Hal tersebut disebabkan tuturan kalimat deklaratif yang disampaikan Nadia masih terdapat kesalahan dalam penggunaan sufiksasi, penyebutan huruf, dan penggunaan kata pronomina. Kalimat Atu kasih bajutu mama secara sintaksis memiliki unsur subjek ganda, yakni (atu) dan (bajutu) sehingga kalimat tersebut tidak berterima secara semantik. Penggunaan kata atu dan bajutu sebenarnya merujuk kepada kata $a k u$ dan bajuku. Penggunaan sufiks -tu pada kata bajutu memiliki makna yang sama dengan sufiks $k u$ yang menyatakan orang pertama. Oleh karena itu, kalimat yang baku sesuai dengan maksud informasi yang ingin disampaikan oleh Nadia, yakni Aku berikan mama bajuku.

\section{Representasi Kalimat Interogatif}

Kalimat interogatif adalah kalimat tanya yang diajukan oleh Nadia secara langsung tanpa memperhatikan aspek sintaksis dan kesempurnaan kalimat yang dituturkannya. Kalimat itu ditunjukkan melalui data (1) berikut ini.

Data (2)

Ibu: Suruh pulang Bapak, Nak!

Nadia: Halo di manati beng, Bapa'?

Nadia: Pulang bapa katanya mamakku!

Ibu: Suruh pulang bapak.

Nadia: Tunggu duyu, sedititpi beng

Ibu: Menelponki, Nak

Nadia: Mama di mana bajutta kaya bajuna mamanna Ana, Ma?

Ibu: Disimpan, Nak

Nadia: Ambil HP0ku, Mama!

Nadia: Apa bilang?

Ibu: Siapa HP itu, Nak?

Nadia: Aku beli HP-ku

Berdasarkan data (2), ada tiga kalimat interogatif yang dituturkan oleh Nadia, yakni (1) Halo di manati beng Bapa? (2) Mama di mana bajuta kaya bajuna mamanna ana ma? dan (3) 
Apa bilang? Usia Nadia yang menginjak 3,6 tahun secara gramatikal sudah mampu berkomunikasi dengan kedua orang tuanya. Kalimat interogatif yang dituturkan Nadia sudah memenuhi unsur sintaksis sebagai kalimat, seperti kalimat Halo di manati beng Bapak. Frase halo dimanati beng berperan sebagai frase predikat dan bapak sebagai subjek. Kalimat tanya tersebut sudah memenuhi ciri sebuah kalimat dengan memiliki subjek dan predikat. Hal ini sejalan dengan pendapat Clark (1977:337) yang mengatakan bahwa struktur tuturan kalimat yang lengkap memiliki kompleksitas yang lebih tinggi dibandingkan dengan struktur kalimat yang pendek.

Tuturan kalimat interogatif sebelumnya masih mengalami proses interferensi. Hal ini ditandai melalui penggunaan kata beng dan sufiks ti. Kata beng adalah bentuk kosa kata yang tidak baku karena digunakan sebagai kata partikel dalam bahasa Makassar. Kata beng setara dengan partikel -kah dalam bahasa Indonesia. Kemudian, penggunaan sufiks ti pada kata dimanati merupakan bentuk sufiks dalam bahasa Makassar. Hal tersebut membuktikan bahwa dalam tuturan kalimat tanya Nadia masih dipengaruhi bahasa ibu yang diajarkan dan dia dengar dari orang tuanya.

Kalimat interogatif yang kedua Mama di mana bajutta kaya bajuna mamanna Ana, Ma adalah sebuah kalimat tanya yang dilakukan secara spontan oleh Nadia. Kalimat interogatif tersebut memiliki makna gramatikal yang menanyakan baju kepunyaan ibunya. Kalimat tanya dalam tuturan itu tidak berhubungan dengan apa yang dilakukan Nadia bersama ibunya saat itu. Pertanyaan tersebut muncul sesuai yang diingat Nadia ketika memandangi ibunya dengan pakaian yang digunakannya. Hal ini sejalan dengan pendapat Sundari (2016:118) yang mengatakan bahwa pertanyaan-pertanyaan yang diajukan anak menunjukkan bahwa anak sedang berusaha memproses informasi bahasa yang diterimanya dan menghubungkan informasi yang telah dimiliki sebelumnya. Anak usia 3,6 tahun seperti Nadia cenderung bertanya secara sporadik di luar konteks ketika dia mengingat sesuatu yang menurutnya cukup berkesan.

Kalimat interogatif ketiga apa bilang merupakan kalimat tanya yang tidak lengkap. Kalimat tersebut tidak memiliki unsur subjek. Subjek dalam kalimat tersebut dilesapkan karena maksud kalimat itu ditujukan kepada ibu Nadia, namun tidak disebutkan namanya. Hal inilah yang membuat kalimat tersebut secara sintaksis dinilai tidak lengkap. Selain itu, tuturan kalimat tersebut dinilai tidak lengkap karena kata bilang harusnya mendapat presposisi di untuk menegaskan kata tersebut. Kata bilang bermakna 'berkata dan mengatakan' sehingga ketika mendapat preposisi di maka kata tersebut bermakna sedang berkata atau dikatakan. Preposisi di selain berfungsi menyatakan keterangan juga berfungsi menyatakan aktivitas ketika bergabung dengan kata kerja. Oleh karena itu, ketika ditulis dalam kalimat lengkap akan menjadi kalimat apa yang dibilang dengan makna gramatikal meminta alasan tentang yang dikatakan oleh ibu Nadia saat itu. Kesalahan pemilihan diksi dalam tuturan anak seusia Nadia masih dinilai wajar. Anak usia 3,6 tahun seperti Nadia belum belum mengetahui proses penempatan afiksasi yang benar. Hal inilah yang membuat tuturan kalimat Nadia masih bersifat mengulang dan bersifat secara sporadik di luar konteks yang dilakukannnya saat itu.

\section{Representasi Kalimat Imperatif}

Kalimat imperatif merupakan kalimat perintah yang dituturkan oleh Nadia agar ibunya mengikuti kehendaknya. Kalimat ini dapat diidentifikasi melalui data (3) berikut ini.

Data (3)

Nadia: Pelgi belitan mama gula!

Ibu: Tidak baik nak makan gula-gula

Nadia: Mauta, Mama!

Ibu: Nantipi pale Nak dibelikan.

Nadia: Mama ambiltan itu!

Ibu: Pulangpi bapak bawa kue di?

Bentuk tuturan kalimat imperatif dalam data (3) mencakup (1) Pelgi mama belitan gula! dan (2) Mama ambiltan itu! Kalimat (1) dapat digolongkan sebagai kalimat perintah karena ditandai dengan kata perintah pergi. Selain itu, pada saat Nadia menuturkan kalimat tersebut di tandai dengan penggunaan intonasi yang tinggi pada kata pelgi dan intonasi rendah pada akhir tuturannya. Hal inilah yang membuat kalimat itu dikategorikan sebagai kalimat imperatif. Secara gramatikal, kalimat imperatif tersebut bermakna menyuruh ibunya membelikan gula-gula. Tuturan tersebut juga sudah lengkap secara sintaksis, yakni pada kata pelgi belitan sebagai predikat $(\mathrm{P})$, mama sebagai subjek (S) dan gula sebagai objek (O). Tuturan tersebut adalah bagian dari cara Nadia memahami situasi dan kepekaannya terhadap lingkungan di sekitarnya, meskipun belum 
mampu menyebutkan kata secara sempurna yang disebabkan keterbatasan alat ucap yang dimiliki Nadia sebagai anak yang baru berusia 3,6 tahun. Namun demikian, Nadia sudah mampu menyampaikan keinginannya dalam bentuk tuturan kalimat imperatif yang bermakna.

Tuturan pada kalimat (2) Mama ambiltan itu juga termasuk sebagai kalimat imperatif. Hal itu ditandai dengan penggunaan kata perintah ambil yang menyuruh Ibu Nadia mengambilkan sesuatu. Penggunaan kata ambiltan yang dikemukakan oleh Nadia seharusnya menggunakan partikel -kan bukan -tan untuk menguatkan maksud yang ingin disampaikan Nadia. Sama halnya dengan kalimat sebelumnya, Nadia belum mampu memahami konsep penggunaan sufiksasi dan kata partikel. Secara umum tuturan kalimat yang disampaikan oleh Nadia masih dipengaruhi oleh penggunaan bahasa ibunya sehingga penggunaan partikel tersebut dinilai tidak baku.

\section{Representasi Kalimat Interjeksi}

Kalimat interjeksi adalah kalimat seru yang dituturkan untuk menyampaikan perasaan tertentu. Kalimat interjeksi tersebut dapat ditemukan dalam data (4) berikut ini.

\author{
Data (4) \\ Nadia: Mana bapak, Mama? \\ Ibu: Ke rumah nenek dulu, Nak. \\ Ibu: Ayo makan, Nak! \\ Nadia: Ah, tidak mauja, Mama! \\ Ibu: Makanki dulu Nak baru pergiki juga sebentar \\ Nadia: Mama, Ayo! \\ Ibu: Mauki ke mana, Nak? \\ Nadia: Itu mama
}

Berdasarkan data (4), tuturan kalimat interjeksi diidentifikasi pada kalimat $A h$, tidak mauja mama. Kalimat interjeksi tersebut merupakan bentuk penolakan Nadia ketika disuruh makan oleh ibunya. Secara umum Nadia sudah mampu menuturkan kalimat-kalimat yang mewakili perasaannya dengan melakukan penolakan ketika dia tidak suka dengan sesuatu hal. Kalimat interjeksi tersebut ditandai dengan kata $a h$ yang dapat diidentifikasi sebagai ketidaksukaan Nadia yang sedang asyik bermain, namun ia diminta melakukan hal yang lain. Kalimat interjeksi tersebut sudah mwakili perasaan dan isi hati Nadia. Oleh karena itu, anak seusia Nadia akan mudah melakukan penolakan ketika memang ada hal yang disuruhkan namun tidak sesuai dengan keinginannya.
Anak usia 3,6 tahun berusaha menjadi produktif dengan menguasai banyak kosa kata baru. Hal ini sesuai dengan pendapat Natsir (2017:26) yang mengatakan bahwa anak usia 3 tahun akan mengalami peningkatan kompetensi bahasa dalam mengekspresikan dan memikirkan berbagai macam objek. Salamah (2015:78) juga menambahkan bahwa anak usia tiga tahun sudah mampu bertutur komunikasi dengan baik dan berusaha menuturkan kalimat secara kompleks meskipun masih terdapat kesalahan di dalamnya. Oleh karena itu, anak usia tersebut mampu merekam bahasa orang dewasa dan stimulus yang diberikan kepadanya meskipun belum mampu mengungkapkan seperti kalimat yang sebenarnya.

\section{Pembahasan}

Melalui analisis data yang dipaparkan sebelumnya diketahui bahwa anak sudah dapat merepresentasikan beragam jenis kalimat meskipun belum sempurna. Anak usia 3,6 tahun sudah dapat memproduksi kalimat deklaratif, kalimat imperatif, kalimat interogatif, dan kalimat interjeksi. Kalimat yang diproduksi anak secara umum ditentukan oleh unsur kognitif. Hal ini sejalan dengan pendapat Tarigan (2011:5) yang mengatakan bahwa kematangan kompetensi bahasa ditentukan oleh aspek biologis, kognitif, dan sosialnya. Pola kalimat yang dituturkan anak di usia tersebut belum lengkap secara sintaksis karena masih terdapat keterbatasan dalam memilih fungsi sintaksisnya.

Pengaruh lingkungan sosial juga dinilai menjadi hal yang mendukung kemampuan kompetensi bahasa anak karena pertambahan kosakata anak diperoleh melalui lingkungan socialnya. Hal inilah yang terjadi pada Nadia sebagai anak yang berusia 3,6 tahun. Secara umum, tuturan yang dihasilkan oleh Nadia dipengaruhi oleh lingkungan sosialnya sebagai pengguna bahasa Makassar. Kesalahan penggunaan afiksasi dalam tuturan sintaksis Nadia menjadi bukti hal tersebut. Nadia cenderung menggunakan proses afiksasi bahasa Makassar dalam tuturan bahasa kedua (B2) yang dituturkannya karena tinggal dalam lingkungan pengguna bahasa Makassar (Mokhtar, 2000). Oleh karena itu, lingkungan sosial anak merupakan bagian integral yang mendukung perkembangan tuturan sintaksis anak.

Faktor lain yang mendukung kematangan tuturan sintaksis anak adalah pengaruh tuturan orang dewasa, anak yang berusia 3,6 tahun sudah 
memiliki kemampuan kognitif untuk merekam bahasa orang dewasa. Hal inilah yang membuat tuturan anak 3,6 tahun cenderung mengulang kalimat yang dituturkan orang dewasa melalui informasi yang telah direkam dalam memorinya. Bahasa orang dewasa adalah citraan yang ditirukan anak secara umum untuk membentuk kematangan kompetensi bahasanya. Tuturan sintaksis pada Nadia merupakan representasi dari bahasa yang digunakan oleh ibu Nadia sebagai orang yang mengasuhnya (Hakim, 2015). Dalam proses berkomunikasi ibu Nadia sering melakukan proses interferensi bahasa. Hal inilah yang membuat Nadia sering melakukan tuturan yang sama ibunya, yakni interferensi dalam tuturan kalimatnya.

Kemampuan berbahasa anak yang dipengaruhi oleh lingkungan sosial dan orang dewasa secara umum telah membentuk kompetensi anak tersebut. Oleh karena itu, kompetensi bahasa anak secara umum dapat dilihat dari kelengkapan struktur sintaksis yang dituturkannya. Anak di usia 3,6 tahun sudah mengenal banyak kosa kata, namun belum memiliki pengetahuan tentang pola dan tata bahasa yang baik sehingga tuturan kalimat interogatif, imperatif, deklaratif, dan interjeksi anak tersebut masih kurang lengkap seperti penggunaan subjek, predikat, dan objek. Selain itu, proses pembelajaran bahasa yang diperoleh anak di usia tersebut masih terbatas. Pembelajaran bahasa yang diperoleh anak diusia 3,6 tahun masih sebatas pengenalan. Oleh karena itu, anak diusia 3,6 tahun belum memiliki pemahaman

\section{DAFTAR PUSTAKA}

Alwi, H. dkk. 2003. Tata Bahasa Baku Indonesia (Edisi ketiga). Jakarta: Balai Pustaka.

Aziz. 2012. Pemerolehan Kosakata Bahasa Pertama Anak Kedua Usia 16 Bulan. Jurnal Re-torika. 8 (2):84-87.

Clark, H. H. and Clark, E.V. 1977. Psychology and Language: An Introduction to Psycholinguistics. New York: Harcourt Brace Jovanovich.

Dardjowidjojo, S. 2014. Psikolinguistik: Pengantar Pemahaman Bahasa Manusia. Jakarta: Yayasan Obor Indonesia.

Hutauruk, B. S. 2015. Children First Language Acquisition At Age 1-3 Years Old In Balata. IOSR Journal Of Humaniora and Social Science (IOSR-JHSS), 20 (8): 51-57.

Miles, M. B. dan Huberman, A. M. 2014. Analisis Data Kualitatif: Buku Sumber Tentang Metode-Metode Baru (Terjemahan Tjetjep Rohendi Rohidi). Jakarta: Universitas Indonesia (UIPress). unsur sintaksis yang baik sehingga hanya mampu berkomunikasi dengan menirukan dan mengulang bahasa yang diperolehnya dalam lingkungan sosialnya.

\section{PENUTUP}

Hasil penelitian menunjukkan bahwa terdapat empat jenis kalimat yang dituturkan oleh Nadia sebagai anak yang berusia anak 3,6 tahun. Keempat kalimat tersebut adalah kalimat interogatif, kalimat deklaratif, kalimat imperatif, dan kalimat interjeksi. Berdasarkan hasil tuturan kalimat Nadia yang berusia 3,6 tahun terdapat sejumlah kesalahan dalam tuturan kalimatnya. Nadia belum mampu melakukan tuturan kalimat secara sempurna karena unsur sintaksisnya belum lengkap, seperti penggunaan subjek, predikat, dan objek. Selain itu, kalimat-kalimat yang diungkapkan masih banyak dipengaruhi oleh bahasa ibu.

\section{UCAPAN TERIMA KASIH}

Penulis menyampaikan ucapan terima kasih kepada mitra bestari (reviewers) yang telah memberikan saran, kritik, dan rekomendasi untuk perbaikan artikel ini. Ucapan terima kasih juga disampaikan kepada orang tua subjek yang memberi persetujuan dan membantu peneliti selama pengumpulan data.

Mokhtar, M. 2000. Interferensi Morfologis Penutur Bahasa Bugis dalam Berbahasa Indonesia. Jurnal Humaniora. 12 (2): 219-224.

Mushaitir. 2016. Pemerolehan Sintaksis (B1) Bahasa Sasak Pada Anak Usia 4-6 Tahun di Lombok Timur Melalui Permainan Tradi-sional. Jurnal Pendidikan Bahasa dan Sas-tra. 16 (1): 33-42.

Natsir, N. 2017. Hubungan Psikolinguistik dalam Pemerolehan dan Pembelajaran Bahasa. Jurnal Retorika. 10 (1): 1-17.

Richard, J. C. and R. Schmidt. 2002. Longman Dictionary of Language Teaching and Applied. Linguistics. London: Pearson Educa-tion, Ltd.

Salamah, S. 2015. Studi Ringkas Pemerolehan Bahasa Anak. Jurnal Bahasastra. 33 (2): 73-82.

Saputri, R. 2018. Pemerolehan Bahasa Anak Usia 3 Tahun. Jurnal Linguistik, Sastra, dan Pendidikan (Jurnalistrendi). 2 (4): 210-214. 
182 RETORIKA: Jurnal Bahasa, Sastra, dan Pengajarannya Volume 11, Nomor 2, Agustus 2018, hlm. 175-182

Sugiyono. 2013. Metode Penelitian Pendidikan: Pendekatan Kuantitatif, Kualitatif, dan R\&D. Bandung: Alfabeta.

Sundari, H. 2016. Pengaruh Input Bahasa Orang Tua Terhadap Kompleksitas Bahasa Anak: Studi Kasus Pada Anak Usia 5 Tahun Melalui Interactive Shared Reading. Jurnal Pendidikan Bahasa dan Sastra. 16 (1): 110-121.

Tarigan, Henry Guntur. 2011. Pengajaran Peme- rolehan Bahasa. Bandung: Angkasa.

Trinowismanto, Y. 2016. Pemerolehan Bahasa Pertama Anak Usia 0 s.d. 3 Tahun dalam Bahasa Sehari-hari. Skripsi. Jogjakarta: Universitas Sanata Dharma.

Usman, H. 2015. Studi Pemerolehan Bahasa pada Anak Usia 4 Tahun. Jurnal Linguistik Terapan. 5 (2): 1-13. 